SR/EMEU/90-1

\title{
Implications of Lifting The Ban on The Export of Alaskan Crude oil
}

MARCH 1990

ENERGY INFORMATION ADMINISTRATION OFFICE OF ENERGY MARKETS PAND END USE

U.S. DEPARTMENT OF ENERGY WASHINGTON， DC 20585 


\section{Implications of Lifting The Ban on The \\ Export of Alaskan Crude Oil}

\section{MARCH 1990}

\section{DISCLAIMER}

This report was prepared as an account of work sponsored by an agency of the United States Government. Neither the United States (jovernment nor any agency thereof, nor any of their employees, makes any warranty, express or implied, or assumes any legal liability or responsibility for the accuracy, completeness, or usefulness of any information, apparatus, nroduct, or process disclosed, or represents that its use would not infringe privately owned rights. Reference herein to any specific commercial product, process, of service by trade name, trademark, manufacturer, or otherwise does not necessarily constitute or imply its endorsement, recom. mendation, or favoring by the United States Ciovernment or any agency thereof. The views and nninions of althors expressed herein do not necessarily state or reflect those of the Uriced States Government or any agency thereof. 
This report was prepared by the International and Contingency Information Division (ICID) and the Economics and Statistics Division (ESD) within the Office of Energy Markets and End Use (EMEU). General questions concerning the contents of the report may be addressed to $\mathrm{W}$. Calvin Kilgore (202/586-1617), Director of EMEU; Mark E. Rodekohr (202/586-1130), Director of IC.ID; or Derriel B. Cato (202/586-6574), Chief of the Analysis Branch of the ICID.

Further information concerning the contents of this report may be obtained from Gerard L. Lagace (202/586-1452). Questions concerning Sections 3, 4, and 5 on the economics of refining should be directed to Phillip Tseng $(202 / 586-1154)$. 


\section{PREFACE}

The Energy Issues group of the United itates General Accounting Office requested that the Energy Information Administration (EIA) analyze the implications of lifting the ban on the export of Alaskan crude oll. This report is the EIA's response to that request. The main objective of the report is to estimate the potential impacts on crude oil and product prices and petroleum trade flows of lifting the ban. 
CONTENTS

Page

Executive Summary $\ldots \ldots \ldots \ldots \ldots \ldots \ldots \ldots \ldots \ldots \ldots \ldots \ldots \ldots \ldots \ldots \ldots \ldots$ vi1

1. Introduction $\ldots \ldots \ldots \ldots \ldots \ldots \ldots \ldots \ldots \ldots \ldots \ldots \ldots \ldots \ldots \ldots \ldots$

2. Alaskan Crude 011 : A Perspective $\ldots \ldots \ldots \ldots \ldots \ldots \ldots \ldots \ldots \ldots$

3. Factors Determinlng the Trade Flow of Alaskan Crude $011 \ldots . . .9$

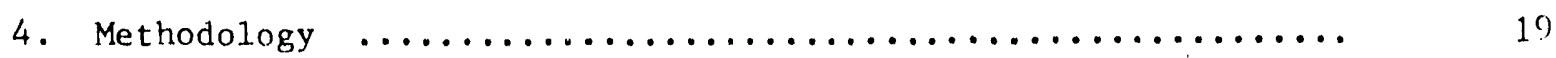

5. Analysis of Results $\ldots \ldots \ldots \ldots \ldots \ldots \ldots \ldots \ldots \ldots \ldots \ldots \ldots \ldots \ldots \ldots \ldots . \ldots \ldots$

6. Broader Implications of Lifting the ANS Crude 011 Export

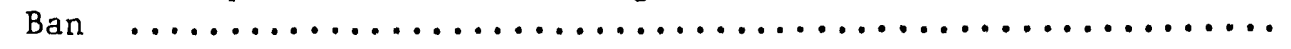

\section{Tables}

1. United States Proved Reserves of Crude 011 at End of Year, $1.977-1988$

2. United States Production of Crude 011, 1976-1995 .........

3. United States Refineries and Refining Capacity as of

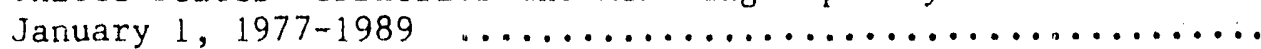

4. Alaskan Crude 011 Receipts at U.S. Refineries, 1981-1988 ...

5. Demand for Petroleum Products in Japan and the U.S. West Coast

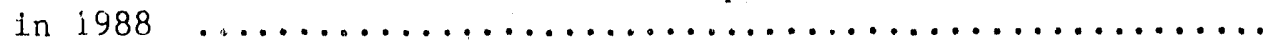

6. Capacities for Key Refinery Processing Untts in Japan and the

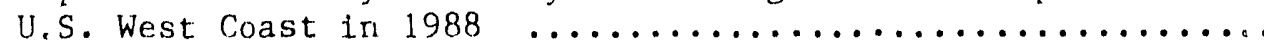

7. Alaskan North Slope Crude 0il Assay .................

8. Potential Price Differemses for ANS Crude Oil on the U.S. West Coast in 1988 


\section{Figures}

1. Comparison of Market Shares in 1988 Demand for Petro eum

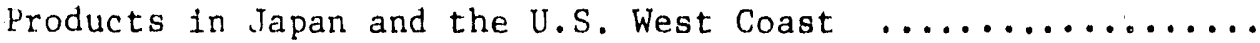

2. Comparison of Cracking Capacities in Japan and the U.S. West

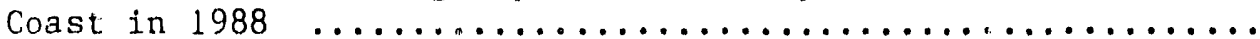

3. Comparison of Major Hydrotreating Capacities in Japan and the

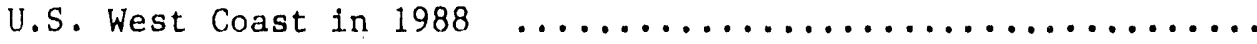


A ban exists on the export of crude oil from the Unfted States. It was imposed on Alaskan North Slope (ANS) crude oil in order to reduce U.S. dependence on 1mported crude and to assure that the Trans-Alaska pipeline would be used to benefit domestic consumers rather than to facilitate exports.

The export ban affects the distribution of ANS crude ofl within the United States and its territories. Nearly three-fourths of that crude is currently shipped to refineries on the U.S. West Coast. Much of the remainder is shipped to the Gulf Coast. Shipments to the Gulf Coast are expected to fall sharply and be all but eliminated during the next few years as West Coast demand increases and ANS production continues to decline.

The elimination of the ban could, and probably would, result in substantial exports of ANS crude to Japan and, possibly, other Pacific Rim countries. This analysis indicates that in the absence of the ban, ANS crude would be valued from $\$ 1.35$ to $\$ 3.39$ per barrel more on the West Coast. This analysis Indicates, therefore, that Alaskan crude oil is undervalued on the U.S. West Coast and that Japan would be a market for ANS crude. Much of this price change can be explained by the fact that Japan uses wuch more middle distillate than does the West Coast and that ANS crude is suited to this production.

There are important qualifications to these model-generated results. First, they are based on 1988 data; but this is not generally considered to be a serious limitation. Second, the model-generated prices are marginal prices for the first barrel of crude oll that would be exported. Additional aNS exports to Japan would revalue all crudes in both markets and ANS prices would probably rise by somewhere between $\$ 1.35$ and $\$ 3.39$ per barrel.

The potential export of ANS crude has additional implications for the U.S. economy. Product prices on the West Coast would increase, but the overall impact on consumers would be minimal. The economy would benefit from gains in economfc efficiency since costs to transport crude from Alaska to Japan would be substantially reduced relative to costs incurred in shipping to the U.S. Gulf Coast. However, the maritime industry would be adversely affected since some part of the domestic tanker fleet used to transport ANS crude would be laid-up if exports to Japan were made in forelgn bottoms. National security could be adversely affected to some extent for the same reason. However, the same effect would occur, albeit later in time, even if the ban rerained in effect since ANS shipments to domestic outlets will drop sharply as the current forecasted decline in ANS production continues. The State of Alaska would henefit from higher wellhead prices. Alaska directly and indirectly derives a large share of its tax revenues from wellhead prices for ANS crude. 


\section{INTRODUCTION}

Present legislation effectively bans the export of crude oil produced in the United States. The ban has been in effect for years and is particularly stringent with respect to crude ofl produced in Alaska, particularly on the North Slope. The Alaska crude export ban is specifically provided for in the Trans-Alaska Pipeline Authorization Act of 1973 and in other legislation. It was imposed for two reasons. The first was to reduce U.S. dependence on 1mported crude oll. The Arab oll embargo had been imposed short1y before the Act was passed and a greater measure of energy independence was considered imperative at that time. The second reason was to assure that funds expended in bullding an Alaskan pipeline would benefit domestic users rather than simply employed to facliltate shipments to other countries.

The ban on exports of domestically produced crude oil is not total. Exceptions are permitted, but the conditions that must be met are stringent. Currently, only small quantities are exported. In 1988, for example, shlpments from the United States and its territories amounted to only 13 thousand barrels per day and were destined only for Canada and China/Taiwan. Exports to the China/Talwan area were from Alaska's Cook Inlet. Licenses to export crude oil. from parts of Alaska's Cook Inlet have been issued since 1986 .

The main objective of this report is to estimate the potential impacts on crude oil prices that would result from lifting the export ban on Alaskan crude o11. The report focuses on the Japanese market and the U.S. West Coast market. Japan is the principal potential export market for Alaskan crude oil. Exports to that market would also affect the price of Alaskan crude ol1 as well as crude oll and product prices on the West Coast and the volume of petroleum imported in that area.

Section 2 of the report presents a perspective on Alaskan crude ofl, production of whlch is decreasing as proven reserves become increasingly depleted. The bulk of the production is shipped to West Coast refineries and much of the remainder to the U.S. Gulf Coast. Shipments to the Gulf

'The term "West Coast," as used In this report, refers to Petroleum Administration for Defense District V (PADD V). PADD V consists of Alaska, Arizona, California, Hawail, Nevada, Oregon, and Washington. 
Coast are expected to fall sharply during the next few years, a result of the expected continued decline in Alaskan production.

Section 3 describes the factors that would determine the trade flow of Alaskan crude ofl if the export ban were abolished. These flows are determined by the demand for petroleum products in domestic and foreign markets, since the demand for crude oll is a derived dewand. The ability of Alaskan crude o11 to satify end-use demand, however, depends on the crude 011 assay of that ofl and refinery conflgurations in various regions, in this Instance the U.S. West Coast and Japan.

Section 4 describes the methodology used in the analysis to generate values for Alaskan crude o11. The Energy Information Administration's (EIA's) Refinery Yleld Model (RYM) is used to generate these values. RYM is a linear programming model whose objective function is to minimize refinery processing costs glven a flxed set of demands for refined products. The model simulates the refining environment in both Japan and the U.S. Hest Coast and takes as given the 1988 values $f$; : product demand slates and refinery configurations in those areas and the characteristics of ANS crude o11.

Section 5 presents the model-generated results and related data. The 1988 value of ANS crude in a free market 18 est1mated to be $\$ 14.85$ per barrel if that crude were processed in a West Coast refinery to meet that refinery's demand slate. This $1 \mathrm{~s} \$ 1.35$ more than the average spot price In Los Angeles of $\$ 13.50$ per barrel for that year. However, if the crude were processed in Japan to meet product demand requirements in that country, the crude is projected to be valued at $\$ 16.56$, and substantial exports of ANS crude to Japan would probably occur. When the value of the ANS crude to Japan 18 adjusted for transportation costs, 1t exceeds the $\$ 13.50$ price of ANS crude on the West Coast by $\$ 3.39$ per barrel. The $\$ 1.35$ and $\$ 3.39$ d1fferent1als are two measures of the potential 1ncrease in the price of ANS crude if the ban were removed. Prices for refined products on the West Coast would also increase. The 1ncrease for gasoline would likely be quite small with most of the price increases concentrated in the heavier refined products.

The 1mputed, or model-generated, values for ANS crude must be interpreted with caution. They are marginal prices. That 18 , they represent the values for the first barrel that would be exported. Additional barrels could cause those values to change with the actual price increase probably somewhere between the two price increase estimates.

Section 6 discusses, in qualitative terms, the broader Implications of exports in terms of government revenues, the balance of trade, the maritime industry, employment, and national secur1ty. Although the mar1time industry would be adversely affected, the overall effect on the U.S. economy could be favorable. 


\section{AIASKAN CRUDE OIL: A PERSPECTIVE}

The discovery of North America's largest oll field at Prudhoe Bay on Alaska's North Slope in 1968 ushered in a new era for Alaska and the U.S. oll market. Major discoverles-min the hundred million barrel range--had previously been made on the Kenal Peninsula and in Cook Inlet in Alaska's Southeastern Region beginning in the $1950^{\prime} \mathrm{s}$. But these discoveries were dwarfed by the Prudhoe Bay fleld which added about 10 billion barrels to estinated U.S. proved reserves of crude o11, an increase of nearly one-third and all of it on State rather than Federal land. Alaska currently accounts for one-fourth of total U.S. proved reserves of crude o1.h, and Alaska and California combined account for nearly one-ha1f (Table 1). Although much of the oll yet to be discovered in the United States is in Alaska, particularly in Federal areas, the discovery of additional flelds approximating the Prudhoe Bay fleld in size is considered unlikely.

Table 1. United States Proved Reserves of Crude 011 at End of Year, $1977-1988$ (Militions of Barrels)

\begin{tabular}{lllll}
\hline Year & Alaska & California & $\begin{array}{l}\text { Other } \\
\text { United } \\
\text { Sta.es }\end{array}$ & $\begin{array}{l}\text { Total } \\
\text { United } \\
\text { States }\end{array}$ \\
\hline 1977 & 8,413 & 5,005 & 18,362 & 31,780 \\
1978 & 9,384 & 4,974 & 16,997 & 31,355 \\
1979 & 8,875 & 5,265 & 15,670 & 29,810 \\
1980 & 8,751 & 5,470 & 15,584 & 29,805 \\
1981 & 8,283 & 5,441 & 15,702 & 29,426 \\
1982 & 7,406 & 5,405 & 15,047 & 27,858 \\
1983 & 7,307 & 5,348 & 15,080 & 27,735 \\
1984 & 7,563 & 5,707 & 15,176 & 28,446 \\
1985 & 7,056 & 5,801 & 15,559 & 28,416 \\
1986 & 6,875 & 5,708 & 14,306 & 26,889 \\
1987 & 7,378 & 5,746 & 14,132 & 27,256 \\
1988 & 6,959 & 5,903 & 13,965 & 26,825 \\
\hline
\end{tabular}

Notes: o Includes both Federal and State of shore. o Sum of components may not equal total due to independent rounding.

Source: Finergy Information Administration, U.S. Crude 011, Natural Gas, and Natural. Gas Liquids Reserves, 1988 Annual Report, DOE/EIA-0216(88) (Washington, DC, October 1989). 
Alaska became a major energy supplier when the Trans-Alaska P1peline System (TAPS) was opened in 1977. Production increased from 173 thousand barrels per day in 1976 to 2.0 million barrels per day in 1988, or nearly up to the IIne's capacity (Table 2). We11 over 90 percent of the cumulative production during this period orlginated from the Prudhoe Bay fleld. Alaskan production declined in 1989 and 1 s expected to continue to fall at a rapld rate for the foreseeable future even if the export ban is removed.

Alaska ships nearly all of 1 ts crude out of State for refining elsewhere. Nevertheless, it does refine about 11 percent of $1 . t s$ own crude and the number of refineries in that State increased from four in 1985 to six in 1987 with a corresponding increase in crude dist11lation capac1ty (Table 3). Roughly one-half of the capacity is in Alaska's Interior Region near Falrbanks. Most of the remainder is refined in the Southeastern Region in Anchorage and the Kenal Peninsula. Only small volumes are refined in the Arctic Region, al1 of 1 t at Prudhoe Bay.

The transport of Alaskan 0.11 is an expensive process and is affected by law and regulations. North Slope crude is 1nitially transported through the 800-mile TAPS plpeline to Valdez, Alaska. The need to amortize the costs of the plpeline, one of the most expensive construction projects ever undertaken, results in a high pipeline tariff. The regulated tariff for oil transported from Prudhoe Bay in early 1990 ranged fron about $\$ 3.47$ to $\$ 4.01$ per barrel.

The natural market for Alaskan crude o11 or a substantial part of 1 t 18 the Paclfic Rim, including Japan. However, the almost total ban on crude o1.1 exports effectively restricts shipments to the United States and 1 ts territories. Further, the Jones Act requires that such shipments be in U.S. constructed vessels fiying. U.S. flags and manned by U.S. crews, which is substantially more costly than using forelgn flag shlps and forelgn crews.

Because of the ban on exports, supply of crude o11 on the U.S. West Coast has exceeded requirements in that area since shortly after the TAPS pipeline was completed in 1977. Alaskan crude o11 in excess of West Coast requirements is shipped to markets on the U.S. Gilf and East Coasts and to the U.S. VIrgin Islands. However, the share of Alaskan crude oll shipped beyond the West Coast has declined substantially since 1982. The particularly sharp decline from 33 percent in 1987 to 28 percent in 1988 reflects an increased utilization of Alaskan crude in West Coast refineries (Table 4). The trend is likely to continue as Alaskan production decreases over time.

The transport of Alaskan crude beyond the West Coast is lengthy and costiy. Costs vary depending in part upon whether the crude oll 1 s transported aboard ship from Valdez for an almost 5,000 nautical. mile Pacific trip through the Panama Canal, or unloaded at one end of the Trans-Panama plpeline and relouded at the other end on smaller U.S. Flag vessels for shiprent to the Gulf and Fast Coasts. Shipments to the U.S. Virgin Islands, however, are not subject to the Jones Act requirements and can be made 1 n foreign bottoms around Cape Horn. 
Table 2. United States Production of Crude 011, 1976-1995

(Thousands of Barrels per Day)

\begin{tabular}{|c|c|c|c|c|}
\hline Year & Alaska & California & $\begin{array}{l}\text { Other } \\
\text { Un1ted } \\
\text { States } \\
\end{array}$ & $\begin{array}{l}\text { Total } \\
\text { United } \\
\text { States } \\
\end{array}$ \\
\hline \multicolumn{5}{|c|}{ A. History } \\
\hline $\begin{array}{l}1576 \\
1977 \\
1978 \\
1979 \\
1980 \\
1981 \\
1982 \\
1983 \\
1984 \\
1985 \\
1986 \\
1987 \\
1988 \\
1989\end{array}$ & $\begin{array}{l}173 \\
464 \\
1,229 \\
1,401 \\
1,617 \\
1,609 \\
1,696 \\
1,714 \\
1,722 \\
1,825 \\
1,867 \\
1,962 \\
2,017 \\
1,874\end{array}$ & $\begin{array}{r}891 \\
958 \\
951 \\
965 \\
975 \\
1,055 \\
1,100 \\
1,109 \\
1,126 \\
1,161 \\
1,114 \mathrm{~b} \\
999 \mathrm{~b} \\
969 \\
\text { NA }\end{array}$ & $\begin{array}{r}7,068 \\
6,823 \\
6,527 \\
6,186 \\
6,005 \\
5,863 \\
5,853 \\
5,865 \\
6,031 \\
5,985 \\
5,699 \\
5,388^{\mathrm{c}} \\
5,154^{\mathrm{C}} \\
\mathrm{NA}\end{array}$ & $\begin{array}{l}8,132 \\
8,245 \\
8,707 \\
8,552 \\
8,597 \\
8,572 \\
8,649 \\
8,688 \\
8,879 \\
8,971 \\
8,680 \\
8,349 \\
8,140 \\
7,631\end{array}$ \\
\hline \multicolumn{5}{|c|}{ B. Forecast ${ }^{\mathrm{d}}$} \\
\hline $\begin{array}{l}1990 \\
1991 \\
1992 \\
1993 \\
1994 \\
1995\end{array}$ & $\begin{array}{l}1,840 \\
1,760 \\
1,630 \\
1,500 \\
1,380 \\
1,280\end{array}$ & $\begin{array}{l}\text { NA } \\
\text { NA } \\
\text { NA } \\
\text { NA } \\
\text { NA } \\
\text { NA }\end{array}$ & $\begin{array}{l}\text { NA } \\
\mathrm{NA} \\
\mathrm{NA} \\
\mathrm{NA} \\
\mathrm{NA} \\
\mathrm{NA}\end{array}$ & $\begin{array}{l}7,370 \\
7,290 \\
7,010 \\
6,780 \\
6,580 \\
6,400\end{array}$ \\
\hline
\end{tabular}

ancludes lease condensate.

Excludes Federal offshore production.

CIncludes Callfornia Federal offshore production.

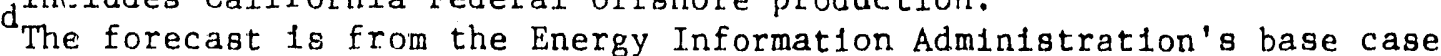
forecast in the source cited below. A range of forecasts is also presented in that source.

$N_{A}=$ Not avallable.

Sources: o History: Energy Information Adminlstraticn, Monthly Energy Review, November 1989, DOE/EIA-0035(89/11) (Washington, DC); and Petroleum Supply Annua1 1988, DOE/EIA-0340(88)/1 (Washington, DC, May 1989) and earlier 1ssues. O Forecast: Energy Information Administration, Annual Energy Outlook 1990, DOE/F.IA-0383(90). (Washington, DC, January 1990) and unpublished supporting documents. 
Table 3. United States Refinerles and Refining Capacity as of January 1 , $1977-1989$

\begin{tabular}{|c|c|c|c|c|c|c|}
\hline \multirow[b]{2}{*}{ Year } & \multicolumn{3}{|c|}{ Operable Refineries ${ }^{a}$} & \multicolumn{3}{|c|}{ Crude Distillation Capacity } \\
\hline & Alaska & California & United States & iniaska & California & United States \\
\hline \multicolumn{4}{|c|}{ (Number) } & nousand & Barrels per & Calendar Day \\
\hline 1977 & 2 & 40 & 282 & 60 & 2.326 & 16.398 \\
\hline 1978 & 3 & 41 & 296 & 83 & 2,378 & 17,048 \\
\hline 1979 & 4 & 42 & 308 & 106 & 2,440 & 17,441 \\
\hline 1980 & 4 & 45 & 319 & 116 & 2,486 & 17,988 \\
\hline 1981 & 4 & 45 & 324 & 123 & 2,475 & 18,621 \\
\hline 1982 & 4 & 43 & 301. & 130 & 2,233 & 17,890 \\
\hline 1983 & 4 & 41 & 258 & 136 & 2,513 & 16,859 \\
\hline 1984 & 4 & 43 & $24 \pi$ & 135 & $2,=24$ & 16,137 \\
\hline 1985 & 4 & 37 & 22.3 & 139 & 2,081 & 15,659 \\
\hline 1986 & 5 & 36 & 216 & 188 & 2,394 & 15,459 \\
\hline 1987 & 6 & 37 & 219 & 225 & 2,431 & 15,566 \\
\hline 1.988 & 6 & 33 & 213 & 223 & 2,379 & 15,915 \\
\hline 1989 & 6 & 32 & 204 & 215 & 2,235 & 15,655 \\
\hline
\end{tabular}

${ }^{a}$ Includes operating refineries and refineries where distillation units are completely idle but is permanently shut down.

Source: Energy Info": nation Administration, Petroleum Supply Annual 1988, DOE/EIA-0340(88)/1 (Wa'sington, DC, May 1989) and earlier 1ssues.

Table 4. Alaskan Crude $0 i 1$ Recelpts at U.S. Refineries, ${ }^{a}$ 1981-1988 (Percent)

\begin{tabular}{|c|c|c|c|c|c|c|c|c|}
\hline District ${ }^{b}$ & 1981 & 1982 & 1983 & 1984 & 1985 & 1986 & 1987 & 1988 \\
\hline PADD I & 5 & 6 & 8 & 6 & 7 & 3 & 2 & 2 \\
\hline PADD II & 3 & 4 & 3 & 2 & 1 & 1 & 2 & 3 \\
\hline PADD III & 16 & 25 & 29 & 25 & 28 & 21 & 21 & 17 \\
\hline PADD IY & 0 & 0 & 0 & & 0 & 0 & 0 & 0 \\
\hline PADD $V^{\mathrm{d}}$ & 63 & 52 & 53 & 58 & 62 & 67 & 67 & 72 \\
\hline Other ${ }^{e}$ & 12 & 13 & 8 & 9 & 3 & 8 & 7 & 7 \\
\hline Tota1 & 100 & 100 & 100 & 100 & 100 & 100 & 100 & 100 \\
\hline
\end{tabular}

${ }^{a}$ Receipts at refineries in the United States and its territories.

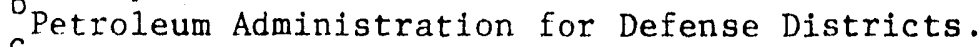

CLess than 0.5 percent.

Hawaiian Free Trade Zone is included in PADD V beginning in 1987.

Other in-ludes the refineries in Puerto Rico, U.S. Virgin Islands and, through 1986, the Hawaiian Free Trade Zone.

NOTE: Sum of components may not equal total due to independent rounding.

Sources: 1986-1988: Energy Information Administration, Petroleum Supply Annual ... (1986-1988), DOE/EIA-0340(86-88)/1, Tab1e 11 and npublished data from Form EIA-810. 1981-1985: unpublished data from Form EIA-810. 
The existence of Alaskan crude oil in excess of West Coast requirements and the need to ship that surplus to other domestic markets has given rise to a "West Ccast discount." Alaskan crude is sold on the West Coast at a price below that for the same crude delivered to the U.S. Gulf Coast. ${ }^{\text {at }}$ The price of Alaskan crude oil to the Gulf Coast is determined by world oil prices in that market. The price of Alaskan crude on the West Coast, on the other hand, is theoretically bounded on the high side by the price of potentially competing world crudes and on the low side by the Gulf Coast average competing crude oil price minus the transportaticn costs between the two coasts. A price for Alaskan crude to the West Coast in excess of the upper bound would theoretically result in reduced sajes (or no sales) of Alaskan crude to that area, and a price below the lower bound would result in increased sales (or all sales) beir. made to the Gulf Coast. In practice, different firms reportedly price Alaskan oil to the West Coast at different levels within these bounds and the magnitude of any discount is highly variable.

If the export ban on Alaskan crude were removed, the price of that crude on the West Coant could rise toward the upper hound (the world price) and the magnitude of any West Coast discount could diminish or disappear, since the world price to both the West and Gulf Coasts does not differ greatly. However, since the volume of Alaskan crude shipped to the Gulf Coast and to other Eastern U.S. markets is expected to decline sharply as Alaskan. production declines as forecasted, any importance attached to the West Coast discount is likely to also diminish even if the export ban is retained.

Although the rhrase "West Coast discount" is used in this report to refer to the price differential for Alaskan crude oil delivered to the Gulf and West Coasts, the phrase has been frequently used by others to describe the delivered price differential between West Coast produced and imported cruge oil.

The magnitude of the discount has been estimated by a number of fndividuals and groups, including estimates prepared for the Alaska senate Flnance Committee. See Institute of Social and Economic Research of the University of Alaska-Anchorage, Report on Alaska Benefits and Costs of Exporting Alaska North Slope Crucle Oil (Anchorage, Alaska: University of. Alaska, May 1987). 


\section{FACTORS DETERMINING THE TRADE FLOW OF ALASKAN CRUDE OIL}

Crude oils differ in quality and price. In general, the sulfur content and API gravity of a specific type of crude oll affect its value. In addition, the first cut (crude oil assay) from a crude oil distillation unit also affects its value; crude oils which produce intermediate products that require less processing to match end-use demand generally command higher prices.

To determine the demand for Alaskan crude o11 outslde the United States requires that potential markets which would be willing to pay a price higher than that on the U.S. West Coast be Identified. That is, if the ban on the export of Alaskan crude were 1ifted, Alaskan crude would flow to foreign refining regions only if the offering price for that crude in those regions were higher than on the U.S. West Coast.

Major factors that determine a particular region's demand for Alaskan crude oll are as follows:

- Demand for refined products

- Refinery configurations

- Crude 011 mixes used in the refinery

- Characteristics of Alaskan crude oil

Potential major markets for Alaskan crude oil are in the Pacific Basin. Japan is the princlpal potential market in that area because of its distance to Alaska and the compatibility of its refinery configurations with Alaskan crude. For this reason, this analysis is restricted to the West Coast and Japan.

\section{Demand for Refined Products}

The composition of demand for end-use products in Japan differed sharply from that on the West Coast in 1988 (Table 5 and Figure 1). The gasoline share of the petroleum market was less than 15 percent in Japan, but exceeded 45 percent on the West Coast. The market share of residual fuel oil was about 18 percent in Japan, but less than 10 percent on the West Coast. And the market share of liquefied petroleum gases (LPG) in. Japan was more than 11 percent, but only about 3 percent on the West Coast. 
Table 5. Demand for Petroleum Products in Japan and the U.S. West Coast in 1988

(Demand in thousands of barrels per day; shares in percent)

\begin{tabular}{|c|c|c|c|c|}
\hline \multirow[b]{2}{*}{ Product } & \multicolumn{2}{|c|}{ Japan } & \multicolumn{2}{|c|}{ West Coast ${ }^{a}$} \\
\hline & Demand & Share & Demand & $\begin{array}{l}\text { Market } \\
\text { Share }\end{array}$ \\
\hline $\begin{array}{l}\text { Motor gasoline } \\
\text { Jet fuel(kerosene) } \\
\text { Distillate fuel } \\
\text { Residual fuel } \\
\text { Other } \\
\text { Jiquefled Petroleum Gases } \\
\text { Natural Gas Liquids } \\
\text { Crude Oil }\end{array}$ & $\begin{array}{r}677 \\
541 \\
970 \\
851 \\
783 \\
536 \\
69 \\
305\end{array}$ & $\begin{array}{l}14.3 \\
11.4 \\
20.5 \\
18.0 \\
16.5 \\
11.3 \\
1.5 \\
6.4\end{array}$ & $\begin{array}{r}1,251 \\
341 \\
423 \\
268 \\
348 \\
68 \\
17 \\
40\end{array}$ & $\begin{array}{r}45.4 \\
12.4 \\
15.3 \\
9.7 \\
12.6 \\
2.5 \\
0.6 \\
1.5\end{array}$ \\
\hline Total. & 4,732 & 100.0 & 2,756 & 100.0 \\
\hline
\end{tabular}

West Coast refers to Petroleum Administration for Defense District. $V$ (PADD V).

Sources: Energy Information Administration, Petroleum Supply Annual 1988, DOE/EIA-0340(88/1) (Washington, DC, May 1989), and Organization for Economic Cooperation and Development, Quarterly 011 and Gas Stat1stics, selected issues.

The significant differences in end-use product demand indicate that the demand for Alaskan crude ofl may also be very different in these two reglons.

\section{Refinery Conílgurations}

Table 6 and Figures 2 and 3 compare capactties for key refinery processing units on the West Coast and in Japan for 1988. The capacities reflect the need and requirement to meet end-use product demand. Two major categories of processing units stand out in the comparison. The first cracks the heavy-end of a barrel to lighter products and the second removes sulfur from the products.

On the West Coast, capacities for Coker, Hydrocracker, and Fluid Catalytic Cracker were 522. thousand barrels per day, 46'; thousand barrels per day, and 773 thousand barrels per day, respectively, 1r 1988. A Coker converts asphall or residual fuel oil to intermediate products to be processed in 


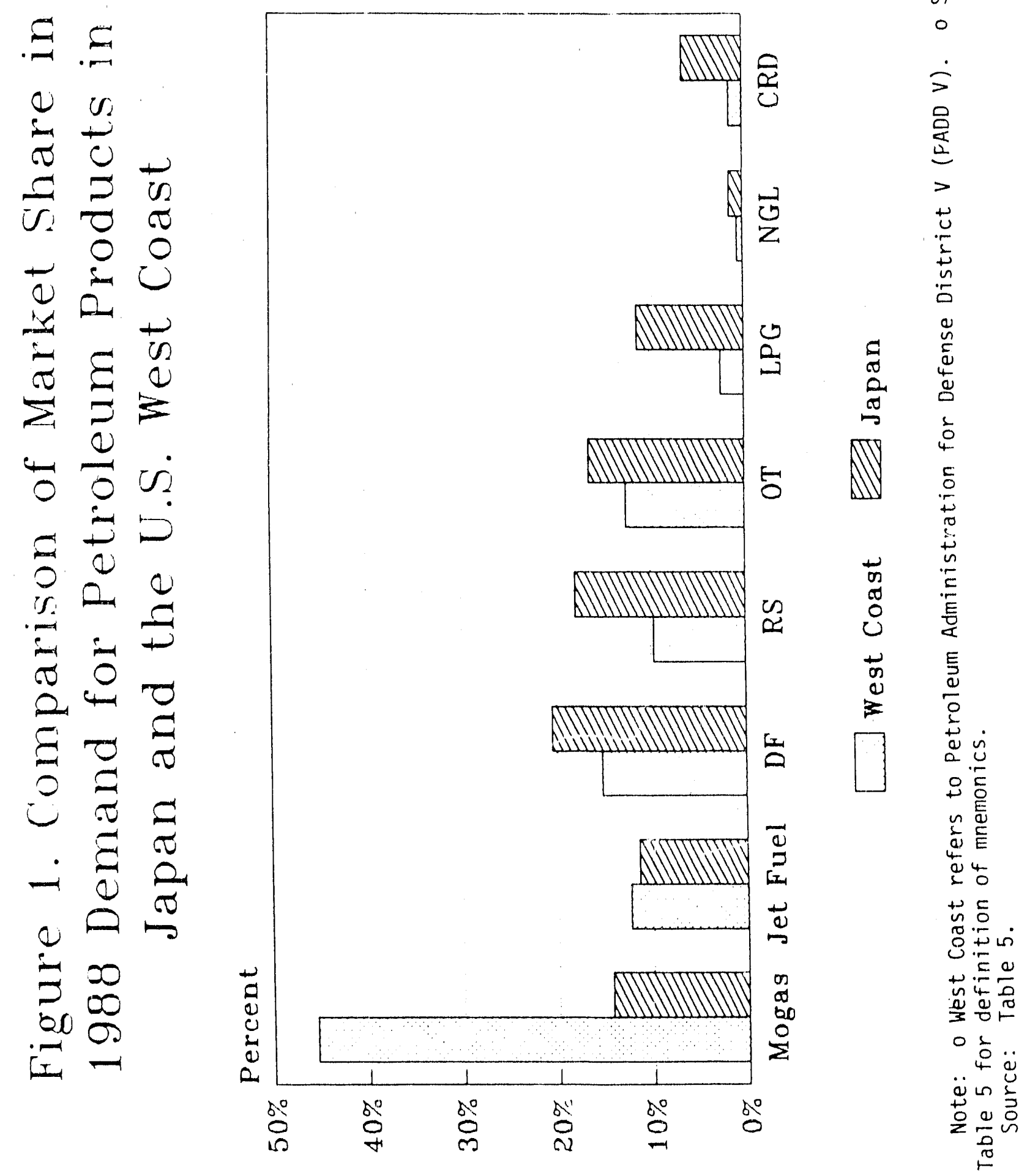


either a Fluid Catalytic Cracker or a Hydrocracker. A Hydrocracker converts higher boiling petroleum materials such as aromatic cycle oils and coker dist11lates into gasoline and jet fuel. A Fluid Catalytic Cracker converts heavy ofl sinto gasoline and lighter products. The capacities for these conve:sion units were substantlally greater on the West Coast than in Japan in 1988. The differences in cracking capacity for these conversion units reflect the effect of a much greater market demand for gasoline on the West Coast with respect to the requirement to convert the heavy-end of a barre1 into lighter products.

Table 6. Capacities for Key Refinery Processing Units in Japan and the U.S. West Coast in 1988

(In Thousands of Barrels)

\begin{tabular}{lrr}
\hline Processing Units & Japan & $\begin{array}{r}\text { West } \\
\text { Coast }\end{array}$ \\
\hline Crude Distillation & $4, j 67$ & 3,231 \\
Vacuum Distiliation & 1,676 & 1,649 \\
Coker-Delayed & 23 & 412 \\
Coker-Fluld & 0 & 110 \\
Viscbreaker & 60 & 64 \\
Naphtha Hydrotreater & 850 & 573 \\
Dist1llate HDS & 1,377 & 373 \\
ICC Feed Hydrofiner & 208 & 490 \\
Resid Desulfurlzer & 1,043 & 235 \\
CAT Reformer High Pressure & 476 & 384 \\
CAT Reformer Low Pressure & 58 & 322 \\
Fluid CAT Cracker & 557 & 773 \\
Hydrocracker & 51 & 465 \\
Alkylation Plant & 11 & 146 \\
\hline
\end{tabular}

${ }^{a}$ West Coast refers to Petroleum Administration for Defense District $V$ (PADD V).

Sources: Energy Information Administration, Petroelum Supply Annual 1988, DOE/EIA-0340(88/1) (Washington, DC, May 1989), and 0il and Gas Journal, Decernber $28,1987$.

In contrast, hydrotreating units in Japan have a much greater capacity than those on the West Coast. In Japan, capacities for Naphtha Hydrotreater, Distillate Hydro-Desulfurlzer, and Residual Fue1 Desulfurizer were 850 thousand barrels per day, 1,377 thousand barrels per day, and 1,043 thousand barrels per day, respectively, in 1988. The differences in the capacities of desulfurlzation units refiect the much greater Japanese demand for naphtha, distillate fuel oil, and residiul fuel o1l, and environmental restrictions on the sulfur content of these fupla. 


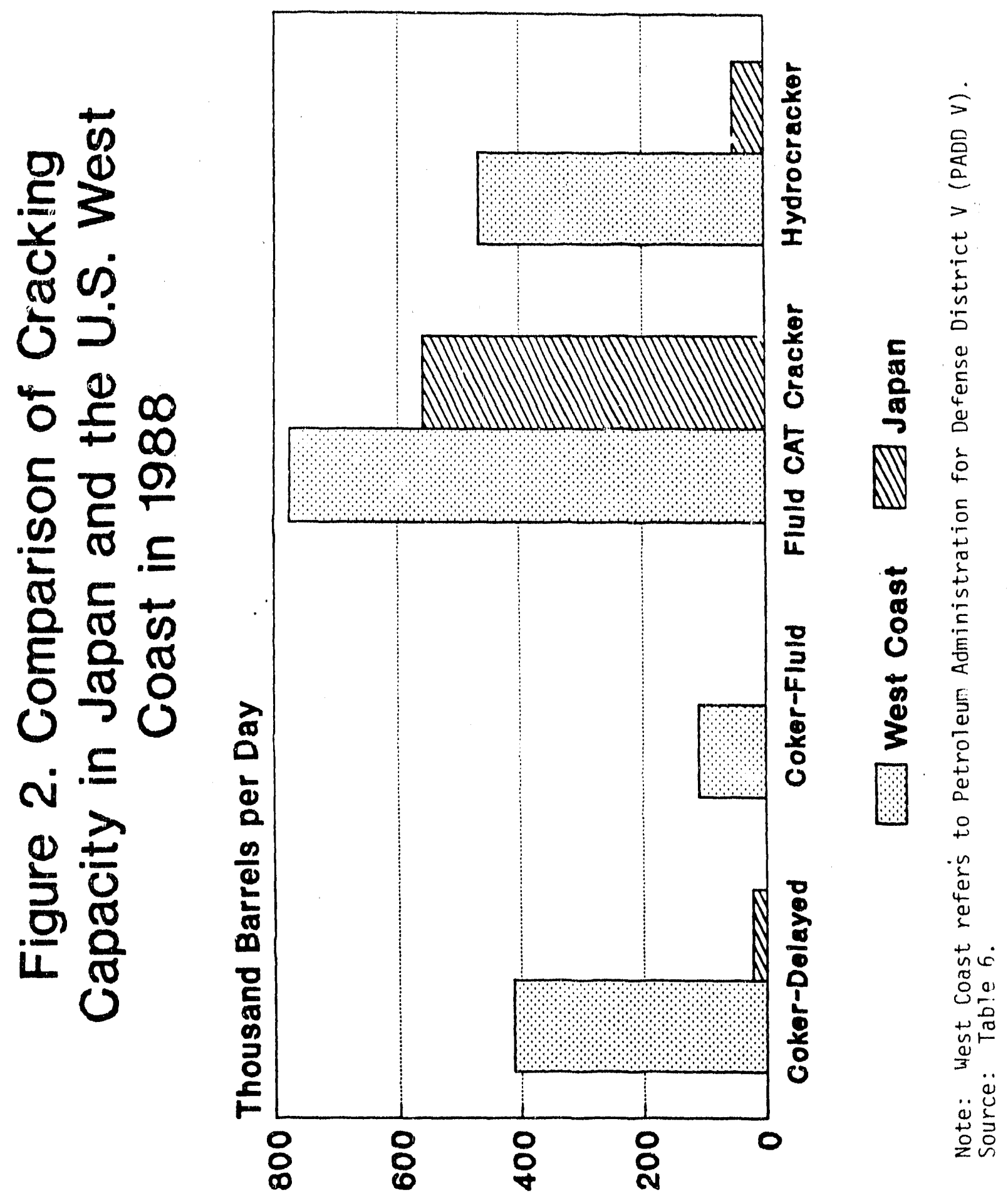




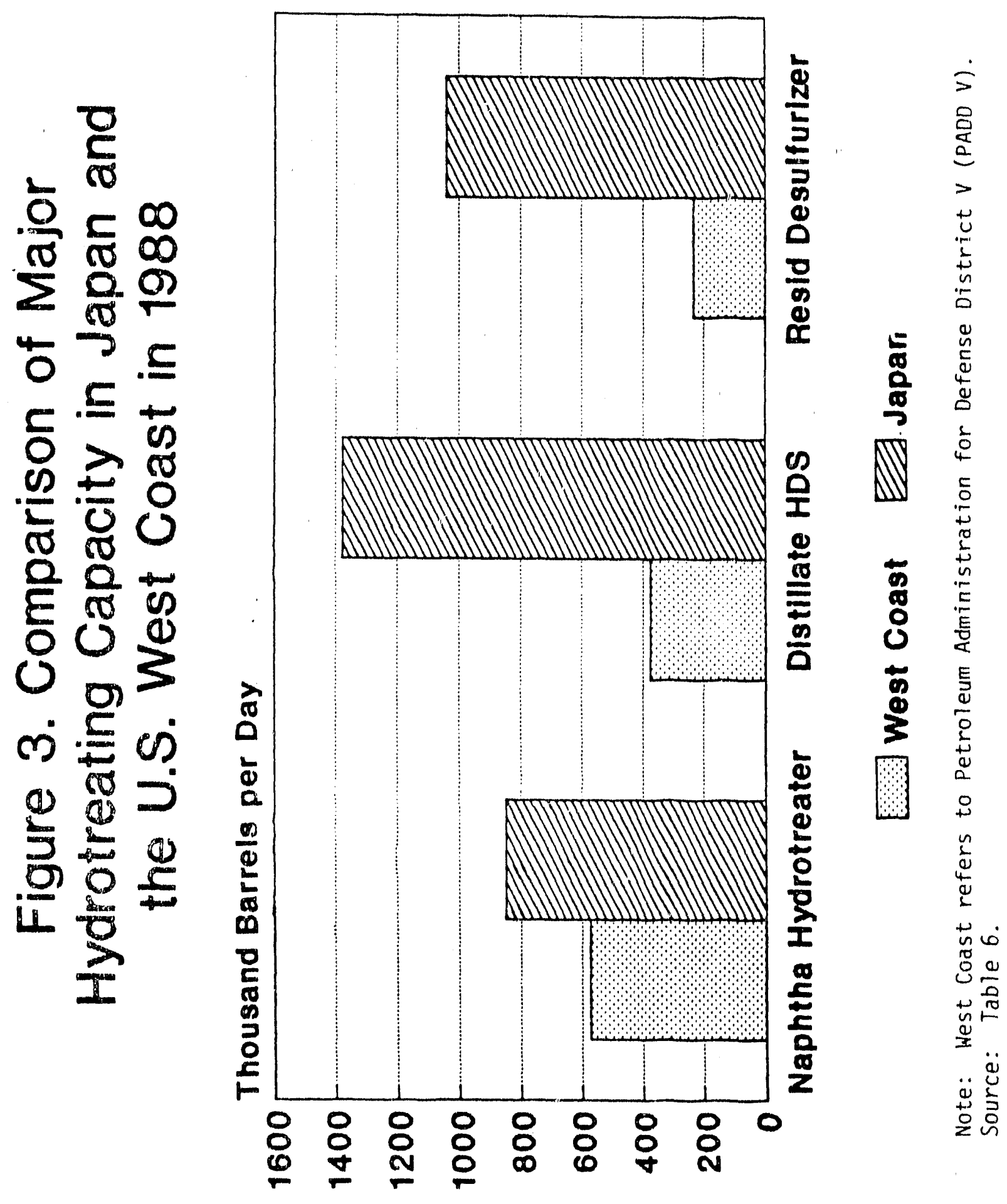


Crude 01.1 Mix Used In the Reflnery

Given the demand for end-use petroleurn products and the refinery configurations, the output of refined products and the efficlency of refinery operations depend largely un the quality and volume of crude streams avallable to a refinery. The optimal crude o11 $\mathrm{mlx}$ would include crude o1ls with sulfur content, API gravity and crude o1l assay that are best sulted for processing in a given refinery and that minfmize the cost of meeting a particular mix of petroleum product demand.

In 1988, Japan imported and processed the types of crude oils shown in the tabulation below. In general, the API gravity of these crudes are higher than $27^{\circ}$, and the sulfur content of most of them are greater than 1.5 percent by welght, except crude olls from China, Indonesia, and Malaysia.

1988 Japanese 011 Imports by Origin

\begin{tabular}{llll}
\hline Australia & Iran Light & Malaysia & Saud1 Heavy \\
ChIna & Iran Heavy & Mexico & USSR \\
Egypt & Iraq & Qatar & U.A.E. \\
Indonesia & Kuwait & Saud1 Light & Venezuela \\
\hline
\end{tabular}

The West Coast imported about 200 thousand barrels of crude o11 per day in 1988. The remaining crude ofl used in that area was indigenous West Coast production, which included about 1.4 million barrels per day of crude from Alaska. The average API g'ravity of the crucle used by the West Coast refinerles was lower (heavier) than for crucle oll used in Japan.

In a competitive oil market, a profit maximfing refiner would be continuously seeking that crude ofl mix which mininizes operating costs and maximizes profits. In general, the optimal crude oll mix to a refinery changes as the demand s.late for refinery products changes.

Characterlstics of Alaskan North Slope Crude 011

Alaskan North Slope crude oll has an API gravity of $26.4^{\circ}$ and a sulfur content of 1.06 percent by weight. The assay of ANS crude indicates that it produces a very small fraction of gasoline range products (1sobutane, light stralght-run gasoline, and light naptha as gasoline blending components). The sum of these fractions is less than 8 percent (Table 7). In a market like the West Coast, which has very high gasoline demand, a great deal more processing is required to convert light gas ofl, heavy gas oil, and residual 
Table 7. Alaskan North S1ope Crude 011. Assay

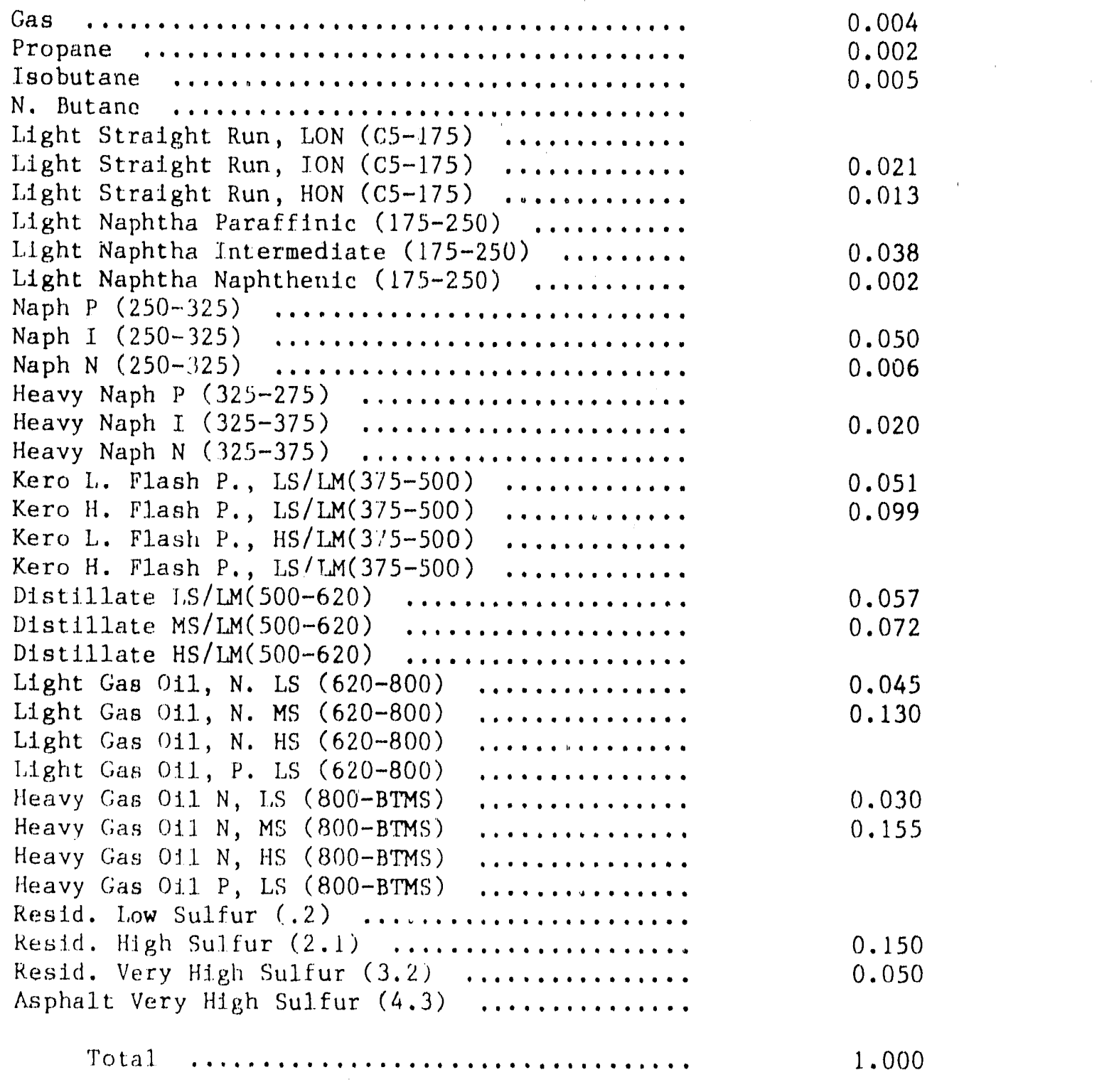

Source: linergy Information Administration, Refinery Evaluation Modeling Systera (RIMS) Mode1 Documentation, DOE/EIA-0460 Washington, DC, October 1984). 
fuel to lighter products such as gasoline and fet fuel. The Fluld Catalytic Cracker and Hydrocracker would be used to convert gas o1ls to gasoline and jet fuel, and the coker process would be used to convert resldual. fuel to lighter products:

In Japan, the demand for distillate fuel and resldual fuel is much greater than the demand for gasoline. Therefore, the processing required to convert the heavy-end of a barrel to 11ghter products is much less. In addition, the low sulfur content of ANS crude o1l also implies a lower utllization of desulfurization units, which further reduces processing costs in Japan.

Would refineries in Japan outbid refineries on the West Coast for at least some portion of Alaskan crude o11? The answer depends on the savings in processing costs that could be achieved by substituting ANS crude oll for other, Imported, crudes as well as on the relative prices of ANS and internationally traded crude o1ls. 


\section{METHODOLOGY}

The economic feasibility of exporting ANS crude ofl can be quantitatively evaluated by simulating market and refinery conditions that refiners face in both Japan and the West Coast. These conditions include demand for petroleum products, refinery configurations, and crude oll mixes. The Energy Information Administration's Refinery Yleld Model (RYM) is suitable for performing such an analysis.

The RYM model is capable of slmulating refinery operations to meet the demand for petroleum products. Given the demand for end-use products and a particular refinery configuration, the RYM model can be solved to either maximize refinery profits or minimize refining costs. Solutions from the RYM model also provide an imputed price for each type of crude o11, based on processing costs which are used as inputs to the model simulations. These imputed prices reflect the combined effects of demand for refined products and refinery processing costs.

Historlc 1988 data on petroleum markets for Japan and the West Coast are used as inputs to the RYM model to simulate refinery operations in these two regions. Specific assumptions and data sources used in the RYM mode1 slmulations are as follows.

\section{Assumptions}

1. The cost of refining for both the crude ofl distillation units and the downstream conversion units are assumed to be identical in Japan and the U.S. West Coast.

2. Crude ofl tanker rates from Valdez to Japan are based on a 175,000 deadwelght ton forelgn flag tanker.

3. The regional refining capacity for each type of conversion unit is the sum of the capacities for this type of conversion unit for each refinery in the region.

\footnotetext{
${ }^{4}$ Energy Information Administration, Refinery Evaluation Modeling System
} (REMS) Mode1 Documentation, DOE/EIA-0460 (Washington, DC, October 1984). 
4. Demand for end-use products in each region $1 \mathrm{~s}$ based on toial 1988 oll demand.

5. Crude o11 inputs to a regtonal refinery are based on regional aggregates for 1988.

6. Refinery output of products in each refinery region is based on regitonal aggregates for 1988 .

7. The FOB price for Saudi Light crude ofl is set at $\$ 14.15$ per barrel. Prices of other crude olls are imputed by the model using the price of Saudi Light as a reference.

\section{Data Sources}

1. The Energy Information Administration's Petroleum Supply Annual 1988 is the primary data source for West Coast crude oli inputs to refineries, production of refined products, and capacity for all refining units.

2. The Organdzation for Economic Cooperation and Development's Quarterly 011 and Gas Statistics and computer printouts from the EIA's December 1989 Internationa1 Petroleum Statigtics Report data base provided data on crude oll imports and production of refined products for Japan.

3. Data on imported refinery acquisition costs in Japan were obtained from the International Energy Agency.

4. The 1988 annual average FOB price for Saudi light is from Petroleum Inte1.11gence Week1.y, January 23, 1989.

5. Tanker rates were derived from Platt's 011gram News, varlous 1ssues published in 1988.

6. The 1988 spot price for ANS crude ofl at Los Angeles was obtained from Telerate System, Inc.

\section{Model Simulations}

The actual historical 1988 data for petroleum markets in Japan and the West Coast reflect the effects of economic forces and institutional factors on these two markets. In particular, the data reflect the effects of interactions among demand for end-use petroleum products, supply of crude oil, and refinery configurations. Institutional factors such as the export ban on ANS crude oll cannot be modeled easily, but the Impacts of such factors can be evaluated with use of the RYM model. The use of 1988 data in 
the model implicitly assumes that refinery operations in those two markets performed efflciently during that year, glven the prevaliling contractual and institutional constraints and practices.

Several steps are required to simulate refinery operations in Japan and to generate a value for ANS crude oll to that country. First, the demand for end-use refined products is fixed at the 1988 level. and composition in the RYM tnodel. Second, the volume of crude o1l, except ANS crude, used by the Japanese refinery 18 upper-bounded. Third, the model is calibrated to match the 1988 imported refinery acquisition custs in Japan. Fixing both the product demand and the upper bound for crude ofl inputs allows direct evaluation of processing costs related to each Lype of crude o11. It also assumes that the petroleum market in 1988 was in equilibrium.

To determine the relative price of ANS crude oll in the two refining regions, and to do so on a common basis, both regions used the CIF Saud1 Light price as a reference price. The reference price was estingted using relevant tanker rates and the FOB Saud1 Light price. 


\section{ANALYSIS OF RESILTS}

Alaskan North Slope crude oil could be shipped to Japan and possibly other Pacific Rim countries if the ban on the export of such crude were eliminated. Because only independent simulations are made here for the two markets, the quantities traded cannot be estimated. However, the high value that Japan places on ANS crude virtually assures that such shipments would occur. Additionally, the price of ANS and other West Coast crude oils would likely increase relative to the price that would exist with a continuation of the ban. These are the direct implications of the results generated by the Refinery Yield Model (RYM). They are based on 1988 data. However, similar results would likely be generated for the early $1990^{\prime}$ 's given recent and expected product demand slates and prices, reflnery conflgurations and crude streams in Japanese and West Coast refineries. Although the RYM model does not generate data for petroleum products, some inferences can be made concerning them based on the RYM-generated data for crude oil prices and information extrinsic to that modei.

Implications for Crude $0 i 1$ Prices and Exports

Two different approaches were used to estimate the difference between the actual price of ANS crude oi.? and 1 ts value 1 n an open, or unconstrained, market. The approaches basically differ accordin's to the particular refinery model used to value ANS crude. The first approach asks what the imputed (or model-generated) CIF value of ANS crude would be if the Alaskan crude were proce.ssed in a West Coast refinery given that refinery's demand slate. The estimate is $\$ 14.85$ per barrel, or $\$ 1.35$ more than what ANS cfude actually sold for to U.S. West Coast iefiners in 1988 (Table 8, Part A). Although this result implies that the market would value ANS crude more than

${ }^{5}$ The $\$ 1.35$ in Table 8, Part A is derived as follows: The FOB price of Saudi Light intended for Japan was $\$ 14.15$ per barrel in 1988 . This price translates to CIF prices of $\$ 14.82$ and $\$ 15.01$ in Japan and the West Coast, respectively, given the known transport costs from Saudi Arabia. Using $\$ 15.01$ as a standard, the RYM model generates, or imputes, a lower ( $\$ 14.85)$ value for ANS crude given the different characteristics of that crude and given the refinery configuration and product demand slate that exists on the West Coast. The $\$ 14.85$ CIF value exceeds the actual average CIF price at which ANS crude sold for in 1988 by $\$ 1.35$. 
Table 8. Potential Price Differences for ANS Crude 0il on the U.S. West Coast in 1988

Method A. Potential. Difference Using West Coast Refinery Mode1

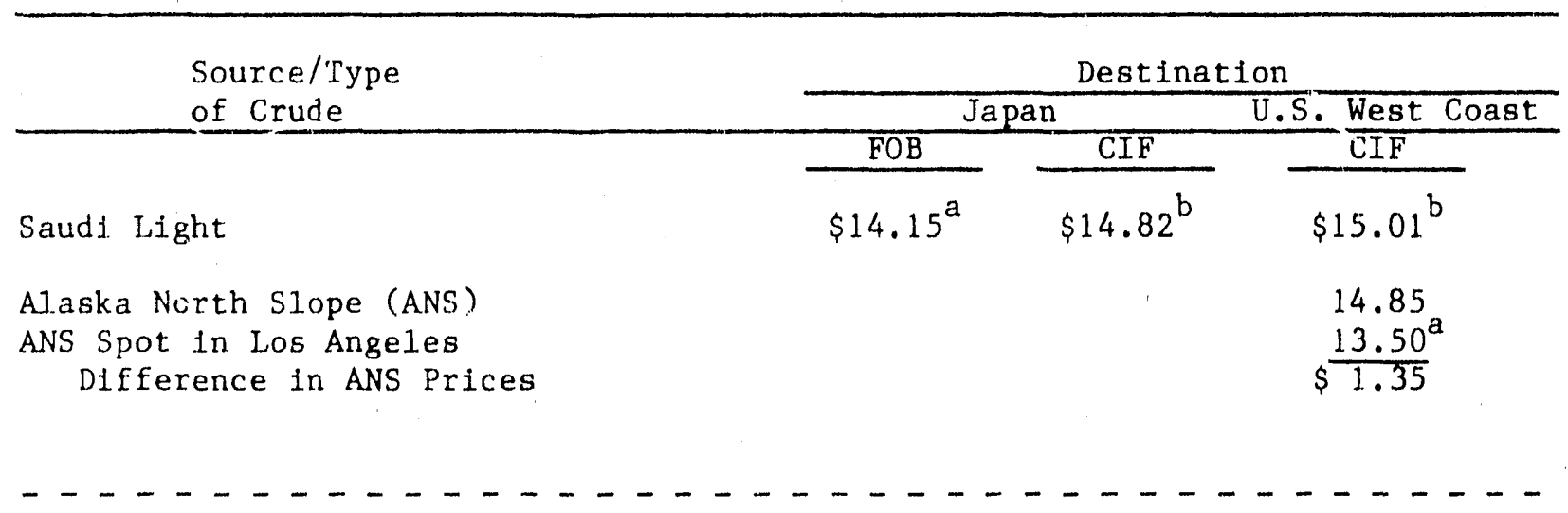

Method B. Potential Difference Using Japan Refinery Model

Saudi Light

A.laska North Slope (ANS)

ANS Spot in Los Angeles

Difference in ANS Prices

$\begin{array}{lll}\$ 14.15^{\mathrm{a}} & \$ 14.82^{\mathrm{b}} & \\ & \$ 16.56 & \$ 16.89 \\ & & \frac{13.50^{\mathrm{a}}}{3.39}\end{array}$

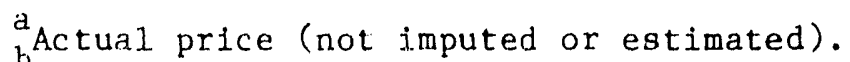

FOB Saudi Arabia plus transportation cost.

Note: West Coast refers to Petroleum Administration for Defense District $V$ $($ PADD V).

Sources: O FOB Saudi Light price: Petroleum Inte111gence Weekly, January 23, 1989. o Transport Costs: Platt's 011gram News, 1988, various issues. 0 ANS spot price in Los Angeles: Telerate Systems, Inc. 0 All other ANS prices: generated by the RYM model. 
its recent actual price if the ban were lifted, it does not provide a basis for determining whether or not ANS crude would likely be exported to Japan or elsewhere in the racific Rim.

The second approach does provide a basis for resolving this issue. It estimates the difference between the actual price of ANS crude and its value using the Japanese refinery model and assoclated product demand slate to value the crude. This second approach asks the following question: What would the imputed CIF value of ANS crude be if it were processed in Japanese refineries? The estimate is $\$ 16.56$ per barrel for ANS crude on a CIF basis to Japan (Table 8, Part B). The implication is that Japan would import crude oil from Alaska if the export ban were abolished. The $\$ 16.56$ value that Japan places on ANS crude delivered to that country is equivalent to a $\$ 16.89$ value on the West Coast when transportation costs are adjusted. The $\$ 16.89$ price is $\$ 3.39$ per barrel more than what ANS crude actually sold for on the West Coast in 1988. The differential is one measure of the magnitude of the increase that could occur in the price of ANS crude if the ban were removed.

The imputed values $(\$ 14.85, \$ 16.56$, and $\$ 16.89$ ) for ANS crude in Table 8 are marginal values, whereas the $\$ 13.50$ price for that crude is an actual average price. The imputed value's represent the values for the first karrel that would be exported. Additional exports would cause the values of crude oils to change in both markets with the 1ikely price increase of ANS crude somewhere between the values estimated here. The implication (from Table 8 , Part B) is that some volumes would likely be exported if the ban were removed and that average prices for ANS crude would rise. Estimates of equilibrium volumes and prices, however, are beyond the scope of the RYM model. Nevertheless, it 1s vary 1ikely that, at a minimum, the 200,000 barrels per day of ANS crude that was recently (1989) shtpped to the U.S. Gulf Coast. would be exported to Japan.

\section{Implications for Petroleum Products}

An increase in the price of Alaskan crude oll on the U.S. West Coast would raise the value of other crude oil.s produced in that region. In addition, higher-priced imported crude olls would be used to replace exported ANS oil. As a result, the average acquisition cost of crude olls and the prices of refined products would increase.

Exporting ANS crude oil and importing gasoline-producing crude oils would free-up the utilization of downstream conversion units. The capacities freed from processing ANS crude oil could be used to process other indigenous West Coast heavy crude oils. This increased capability of processing heavy crude oils would enable refiners on the West coast to produce additional volumes of 1 ighter products and could raise the demand for and the prices of Indigenous West Coast heavy crude ofls. 
Prices for refined products would also increase due to an increase $i$ refinery acquisition costs. The magnitude of the price increase, however, would not be the same for all products. Price increases for 1 ighter products such as gasoline and distillate fuel oil would be expected to be relatively small. First, the exportation of ANS crude 011 and the importation of gasoline-producing crude olls would reduce refiners' processing costs, which could offset part of the increase in refiners' acquisition costs. Second, in a competitive international market, free trade in petroleum products assures that differences in product prices across international refining regions would not exceed transportation costs.

Price increases for residual fuel ofls would probably be significantly greater than for lighter products. Historically, there is a general parity between the prices for crude ofl and residual fuel; an increase in the price of crude oil inputs to West Coast refineries would certainly raise the price of residual fuel. Market forces would also ensure higher prices for residual fuel; production of residual fuel oil would decline because imported crude oils produce a smaller volume of residual fuel. In addition, the exportation of ANS crude oil would enable refiners to convert more heavy crude $0 i 1$ to produce lighter products.

Generally, lifting the export ban on ANS crude oll would likely have little impact on consumers. The economic lmpact on industrial users would not be very great because the share of residual fuel oil in total energy consumption in both industrial use and power generation is very small. 


\section{BROADER IMPLICATIONS OF LIFTING THE ANS CRUDE OIL EXPORT BAN}

The elimination of the ban on ANS crude oil exports has implications for the economy that extend beyond the direct effects on petroleum prices and trade flows. These additional effects relate to petroleum producers and production, the domestic distribution of Alaskan crude, the shipping industry, government revenues, the balance of trade, ano national security. This section qualitatively explores some of these additional effects. Quantitative estimates are beyond the scope of this report.

The removal of the export ban on Alaskan crude oll would cause the volume of crude exported to foreign countries to rise substantially from its present negligible level. The so-called ofl glut on the West Coast would diminish and wellhead prices in Alaska and elsewhere on the West Coast would increase. Wellhead activity in Alaska and in California would probably also increase relative to the level of activity with the ban in effect.

The removal of the ban would have favorable and unfavorable effects on the petroleum industry. The direct increase in export prices together with export shipments in forelgn bottoms at lower rates would result in higher wellhead prices and profits for producers of crude o1l, at least in Alaska. Conversely, some refiners on the West Coast could be adversely affected by the increase in ANS and, possibly, California crude ofl prices. This adverse effect would be offset to only a minor extent by the expected small increase in average prices for products.

The U.S. tanker fleet would be adversely affected if the Alaska export ban were eliminated. However, adverse effects on that portion of the fleet used to ship ANS crude to the Gulf and East Coasts would be quite small since shipments to those areas would be all but eliminated by 1992 (ard possibly earlier) even with the ban in effect, because of the expected continued

${ }^{6}$ The most comprehensive published set of quantitative estimates of both the direct and broader effects of eliminating the export ban is in U.S. Department of Commerce, Report to Congress on Alaskan 011 (Washington, DC, June 1986). Also see Marshall Hoyler, "The Politics and Economics of Alaskan 011 Exports," U.S.-Japanese Energy Relations (Boulder, Colorado: Westview Press, 1984), pp. 83-137; and Institute of Socjal and Economic Research of the University of Alaska-Anchorage, Report on Alaska Benefits and Costs of Exporting Alaska North Slope Crude O11 (Anchorage, Alaska: University of Alaska, May 1987). 
sharp decrease in ANS production. Removing the ban would simply accelerate the process somewhat. Tankers involved in the intercoastal trade on the West Coast, on the other hand, would be more adversely affected. Over a longer pertod, they would also be affected to the exten: that exports to the Pacific Rim are made in foreign bottoms, which is likely. A large share of the deadwelght tons of that fieet is used to transport ANS crude. The layed-up tonnage would adversely affect the profitability of owners of tankers, could cause some defaults on tanker loans, and result in layoffs of seamen for whom alternative employment is not readily available. Employment in the shipbuilding and repair industry would also be impacted. The Federal government could also be adversely affected by developments in the tanker industry, since some of the tanker loans which might go into default are Federally guaranteed.

The fncrease in the prices, and possibly volumes, of ANS crude oil production that would result from eliminating the export ban would have a favorable effect on State government revenues in Alaska. A large share of Alaska's revenues, and most of its tax revenues, are tied directly or indirectly to wellhead prices through severance taxes on o11 and gas, conservation taxes, taxes on producing properties, and corporate income taxes. Severance taxes alone accounted for two-thirds of Alaska's State government tax revenues in fiscal 1988. The State government also collects lease royalties of 12.5 percent of the wellhead value of crude petroleum produced in the Prudhoe Bay field since that field is on State-owned land. Higher crude oll prices ard increased production volumes would cause State tax and royalty revenues from all of these sources to increase over the near term relative to the revenues that would otherwise be generated. Callfornia tax and related revenues from its indigenous crude would also increase for similar reasons but to a lesser extent since it has only a negligible severance tax.

The effect on the U.S. balance of trade from ellminating the ANS crude o11 export ban is uncertain. The net effect depends on many factors, including (1) whether exported crude would be replaced with imported crude on a barrel-for-barrel basis, (2) potential increases in the volume of product imports, (3) increases in West Coast crude oll production, and (4) the extent to which West Coast petroleum product consumption would decline as a result of higher production prices in tinat area. Although the net effect on the balance of trade is uncertaln, the effect on only the balance of trade in servfces would clearly be unfavorable if both the ANS oil which is exported and the compensating volumes that are imported were all shipped in forelgn bottoms.

The national security implications of lifting the ban on the export of ANS crude oil are complex. The additions to total ANS crude oil production from higher prices enhances security since it makes more domestic oil available to the world market. U.S. dependence on petroleum imports, measured as the ratio of net imports of crude oil and products to petroleum products supplied to the U.S. market from all sources, would decrease to the extent that the increase in import volumes from eliminating the ban 1s less than the export volume. Nevertheless, the U.S.'s net dependence on imports from 
members of the Organization of Petroleum Exporting Countries (OPEC) would increase to the extent that the increase in the volume of Imports is from that group. Within a broader geographic framework, however, the dependence of Pacific Basin countries on OPEC would decrease as they diversify their sources of crude oll supply to Include Alaska. 

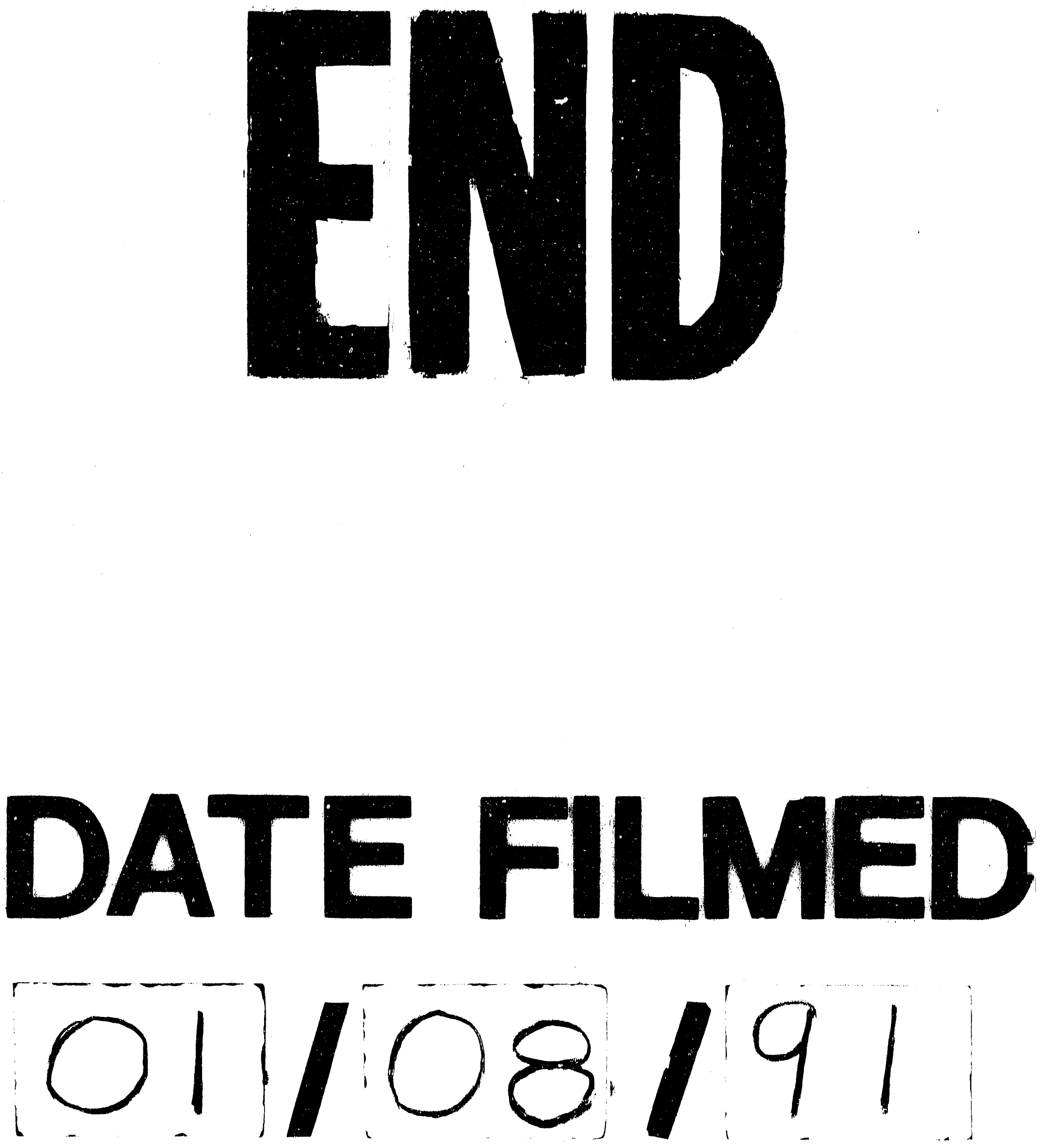
